\title{
A Few Times a Year
}

National Cancer Institute

\section{Source}

National Cancer Institute. A Few Times a Year. NCI Thesaurus. Code C159851.

Happening a few times during a year. 